\title{
Business Ethics Scenarios: The Right And The Wrong Of It
}

Carolyn Ashe, (Email: ashec@uhd.edu), University of Houston, Downtown

\begin{abstract}
Organizations such as Shell Corporation and Lockheed Martin have used scenarios for decades as a learning and visionary tool to address domestic and global issues in their corporatelorganizational culture. Today scenarios dealing with practical business issues are used to encourage students in the classroom to discuss and consider the possible decisions that can be made when responding to everyday business issues.
\end{abstract}

\section{INRODUCTION}

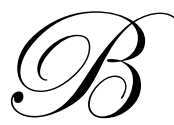

elow are four scenarios with teaching notes that can be used to introduce ethical topics for discussion in a business ethics class. The scenarios can also be used as a supplement in other business classes for ethical discussion to satisfy the AACSB requirement.

\section{SCENARIO 1: MY WAY OR THE HIGHWAY ATTITUDE}

You have been working for a large corporation for three years. The job is tough and you have fought your way up the ladder of success. The manager of your department was your co-worker from two years ago and the power has gone to her head. She is overly demanding and has my way or the highway attitude that grates on your nerves daily.

Six months ago, Trish was hired in a position three levels above yours due to years of accounting and SEC reporting experience. Trish and your manger never see eye-to-eye on any issues and there are daily battles between them that you observe. This person talks non-stop most of the day and sits across from you in a cube environment.

One day after a particularly ugly discussion with your manager, this person comes to you and informs you that she is going to quit her job and sue the company. She believes that the manager is treating her unfairly and that it constitutes harassment. You smile politely and blow off the comment as just anger being vented due to the current situation and go on with your day. As time progresses, you hear this same comment about suing the company several more times from your co-worker and you hear her discussing this with several other members of your department.

What do you do?

- $\quad$ Take the co-worker aside and tell her to stop making the comments.

- $\quad$ Go to your manager and tell her what the co-worker is saying.

- $\quad$ Keep to yourself and make no comments to anyone in the organization.

- $\quad G o$ to Human Resources and report your co-worker's behavior and threats.

\section{Teaching Notes}

Your first choice should be A: Take the co-worker aside and tell her to stop making the comments. Many people are often unhappy with their jobs and/or management and vent by making various comments about disliking this person or that person, despising management and their tactics, etc. But this does not mean they will ever take any kind of action. By going to management or Human Resources, you may be causing a situation that will both alienate 
you from your work group and the person making the comments. This could also backfire and make you look bad to upper management for not being a team player and keeping these internal comments to yourself.

\section{SCENARIO 2: THE HIDDEN GIFTS}

Paula is 20 years old working for an employee health clinic at a local medical school. Paula files, runs errands, types correspondence and orders supplies for the office and clinic. She initiates all of the orders to the appropriate vendor when the nurses inform her that they are running low on supplies.

However, there is one vendor that calls her regularly to see if they need gloves or syringes. When supplies were low, Paula would have this vendor fill the order. One day, she received a package from this company. Inside were an underwater camera and a note thanking her for the business.

A few weeks later the vendor called to get approval to ship more supplies. Paula declined as informed him supplies were not low. The salesperson became annoyed and reminded her that they were under a contract and would face a penalty if the supplies were not shipped and paid for within a specified time period. Paula knew nothing of a contract and assumed that it was set up before she started working there. The salespersons told her that after payment was received, they would send her a stereo to thank her for continued business.

What do you do?

- $\quad$ Have the salesperson speak to her supervisor.

- $\quad$ Call the legal department.

- $\quad$ Decline the gift.

- $\quad$ Ask for a copy of the contract.

- $\quad$ Tell the salesperson to ship the supplies and receive the stereo in a few weeks.

\section{Teaching Notes}

Answers A, B, C, D or a combination of any of the options is what might be selected. Not only could accepting these gifts appear unethical, it is most likely against company policy to do so.

This scenario actually happened. Months later, the vendor sent a television set. The television set was left in the office. Paula felt bad about accepting the stereo and camera as well as the television (but obviously not bad enough). Some time passed and the company called to collect the money they claimed was owed. By that time, management had changed and Paula felt she must confess to what has taken place. Her company admitted to recording her phone conversations without her knowledge. There was never a contract. The legal department became involved. Fortunately for Paula everything worked out and 10 years later, she was still employed at the company.

\section{SCENARIO 3: INSIDER THEFT}

Marie Fox is an assistant manager at a retail-clothing store. She is aware of numerous incidents of insider theft. The cash drawer is always short several dollars at a time and there are bogus returns with a common customer. Her manager, Paul Martin is also her friend. She has worked with him at other companies and he is responsible for her obtaining her present job as an assistant manager. Marie is in charge of the paperwork that deals with customer returns, deposits, and inventory. The entire staff only consists of six people, including the manager, Paul and assistant manager, Marie. Everyone is aware of the problems and Paul is telling you the sales associates are the ones he is suspicious of. You know that only the manager and assistant are allowed to do the deposits, paperwork, and all returns. All the clues are pointing to your manager, but he insists it is the lower level employees. All cash drawer shortages are reported to the corporate office of the company and it reflects on you. The customer that keeps getting the returns comes in and tries to return items that don't have a receipt. Marie is already aware of the bogus returns and declines the return without proof of purchase. Paul realizes at this point that Marie has proof that he is acting 
unethically and in turn harming the company. She believes that most likely there are other instances of Paul's unethical behavior.

What do you do?

- $\quad$ Keep quiet and continue to work under those unethical conditions so you don't ruin your relationship with your manager and friend.

- $\quad$ Go above his head to the District Manager and bring the proof of all the transactions.

- $\quad$ Confront your manager and tell him you know and threaten to tell if he does not cease his unethical behavior.

- $\quad$ Let him accuse innocent employees and let them get fired for his unethical behavior.

\section{Teaching Notes}

You should go above his head to the District Manager and bring proof of all the transactions and let the company handle the situation. Regardless of your personal relationship with the manager you need to make a decision whether to condone his behavior or do the right thing, especially since someone else may be accused of his actions. Organizations lose money annually to theft which is passed on to the consumer. In some instances, the loss can be so great that the organization is forced to close the doors.

\section{SCENARIO 4: HONESTY AND FAIRNESS}

Margaret works in the Marketing Department for a large American multi family housing company. Recently she was told the company would be hiring to fill the Regional Marketing Director (RMD) position in the Central Region. The position has been vacant for a long time and Margaret has been performing the duties for both her job and the job of the RMD. However, the work has begun to be too demanding and you have been working overtime to complete both jobs. Therefore, filling the RMD position is going to help lessen your workload.

Margaret's supervisor, Paul Smith has made the final decision about who should be hired for the RMD position. The company has a process for new hires to complete that include paperwork that personnel in the Human Resources department help the new employee to complete. Part of the process for the new employee is the completion of a drug test. The company has a strict drug free workplace policy. Every new employee must pass a drug test prior to receiving a written agreement of employment from the company. The candidate that Paul wants to hire is working with the Human Resources department completing paperwork to take to the lab for the drug test.

A coworker of yours in Human Resources, in a conversation the two of you were having, tells you that the candidate listed on her paperwork medications she is currently taking as folic acid and prenatal vitamins. She also reveals she could be pregnant. Although you know it is not required for an employee to tell a potential employer that you are or might be pregnant, still you feel betrayed. You are worried that you will spend the next six months training the new employee and after such time, she will go on maternity leave or worse, quit. Once again you will be doing two jobs. Margaret is also concerned that the candidate might be taking the job just to receive insurance benefits until after the baby arrives.

What do you do?

- $\quad$ Since the offer letter is still pending, tell Paul you accidentally heard the candidate might be pregnant and hopefully he will pick another candidate.

- $\quad$ Ask your coworker in Human Resources to "accidentally" mention the new employee may be pregnant.

- $\quad$ Ask your coworker to advise the new employee to tell the supervisor she is pregnant.

- $\quad$ Say nothing. Knowing that your coworker in Human Resources honestly let confidential information slip and saying anything could jeopardize her job. 


\section{Teaching Notes}

Answer D is most appropriate for two reasons. One that you know your coworker unintentionally revealed the information about the new employee and second, the new employee is not required to reveal to the company information about her pregnancy. As a matter of fact, to require the new hire to do so would be against the law. If Margaret was to try to reveal the information she learned, this could possibly lead to other employment problems and still not prevent the person from being hired.

\section{CONCLUSION}

The scenarios should be used to provoke critical thinking among students encouraging them to determine if what they would actually do is the same as what they should do. Students should discuss their responses among each other as well as determine possible alternative solutions. Determining the right and wrong of a situation is influenced by the experiences, backgrounds, and outside influences of the participants as well as how closely associated with the situation one is.

\section{REFERENCES}

1. ETHEX: Exploratorium's Ethical Scenarios Forum (2005). Retrieved August 20, 2005 from http://www.exploratorium.edu/genepool/ETHEX.html

2. Ethical Dilemmas: What is the Morally Right Thing To Do in the Cases (2005). Retrieved August 15, 2005 from http://www.cariboo.bc.ca/ae/php/phil/mclaughl/courses/ethics/bioeth/dilemmas.htm

3. Keying In, The Newsletter of the National Business Education Association, Vol. 15, No. 3, pp. 1-2, January 2005. 